\title{
Mesterképzés tanítóknak
}

\section{Serfőző Mónika}

Eötvös Loránd Tudományegyetem Tanító- és Óvóképző Kar, egyetemi docens, e-mail: serfozo.monika@tok.elte.hu

ORCID: 0000-0002-5552-8828

A tanitóképzés történetében mérföldkó volt a „többciklusú, lineáris felsóoktatási képzési szerkezet" (252/2004. (VIII. 30.) Kormányrendelet) bevezetése 2006-ban. A tanitóképzés „zsákutcás” jellegének (Bollókné \& Hunyadyné, 2003) megoldására is lehetőséget kínált ez az átalakulás, a neveléstudományi mesterszak megalapítása. Kinyílt az egyetemi továbbhaladás lehetósége úgy, hogy a korai nevelés pedagógusai nem kényszerültek jelentós szakma- vagy pályamódositásra, lehetőségük lett a doktori fokozat megszerzésére is. A tanulmány a neveléstudományi mesterszak rövid történetét, a képzés sajátosságait, részletesebben az első, meghatározó Kora gyermekkor pedagógiája szakirány koncepcióját mutatja be. Tükrözi Hunyady Györgyné világos elképzelését arról, hogy a mesterképzés hogyan járul hozzá a hallgatók, a kora gyermekkori nevelésben szerepet vállaló pedagógusok és egyáltalán a szakterület fejlődéséhez.

Kulcsszavak: tanitóképzés, neveléstudományi mesterszak, kora gyermekkor pedagógiája

DOI: 10.37205/TEL-hun.2019.ksz.05

A tanítóképzés történetében is mérföldkő volt a „többciklusú, lineáris felsőoktatási képzési szerkezet” (252/2004. (VIII. 30.) Kormányrendelet) bevezetése 2006 szeptemberétől. A többciklusú képzési rendszer kialakítása („bolognai folyamat”) során minden tudományterületen újra kellett gondolni az alap- és mesterszakok helyét, célját és képesítési követelményeit (Brezsnyánszky \& M. Nádasi, 2008).

Egy régóta megfogalmazott probléma, a tanítóképzés „zsákutcás” jellegének (Bollókné \& Hunyadyné, 2003) megoldására is lehetőséget kínált ez az átalakulás. A „zsákutcás” kifejezés arra a problémára utal, hogy a tanító vagy óvodapedagógus szakon végzetteknek korábban nem volt előrelépési lehetősége. Csak úgy szerezhettek magasabb végzettséget, egyetemi diplomát, ha elvégezték az ötéves pedagógiaszakot vagy pályát módosítottak és bekapcsolódtak a tanárképzésbe, ezáltal is megerősítve a tanító-tanár szerepek közötti hierarchiát. A továbblépés ezekben az esetekben is a képzés elölről kezdését jelentette, nem volt ráépülési, összeépülési lehetőség, legfeljebb egy-egy korábban elvégzett kurzust lehetett beszámítatni (Bollókné \& Hunyadyné, 2003). 
A többciklusú képzési szerkezet kialakításának egyeztetései során az óvodapedagógus és tanító képzési ág képviselői olyan megoldásra törekedtek, amely:

- megőrzi a tanító szak értékeit, kidolgozott jellegzetességeit (felsőfokúvá válás, négyéves tanítóképzés),

- megőrzi a tanítók és óvodapedagógusok képzés során szerzett kompetenciakörét (3-6, illetve 6-12 éves gyerekek nevelése, oktatása),

- a szakmai karrierépítés lehetőségét úgy biztosítja, hogy a tanítóknak nem kell elszakadni a tanítói munkától, foglalkozhatnak tovább azzal a korosztállyal, akihez elköteleződésük és szakmai elképzeléseik, terveik füzik őket (Bollókné \& Hunyadyné, 2003).

Ezen célok mentén született meg az az elképzelés, hogy a tanító szak az alapszakokkal egyenértékű végzettséget adjon és a bölcsészettudomány képzési területhez tartozó neveléstudományi mesterszak révén legyen lehetőség megemelni a végzettség szintjét. Ez elméleti téren nagyobb kitekintést, kutatáshoz kapcsolódó kompetenciák fejlődését jelentette, ezáltal lehetőség nyílt a doktori fokozat megszerzésére is a tanítók és óvodapedagógusok számára.

Bollókné \& Hunyadyné (2003) szerint ez a koncepció lehetővé tette, hogy megmaradjanak a szakcsoportban kialakult képzési profilok, azok erőteljes gyakorlati irányultsága, de kinyílt az egyetemi továbbhaladás lehetősége is úgy, hogy a korai nevelés pedagógusai nem kényszerülnek jelentős szakma- vagy pályamódosításra.

Korábban is a tanítók és óvodapedagógusok képezték az ötéves pedagógia egyetemi szak bázisát, így kézenfekvő volt, hogy 2005-2006-ban is ezen a területen gondolkodtak az alapszakok továbbhaladási útjának kialakításában.

Hunyady György, a bölcsészkari dékánok szakmai kollégiumának szakági koordinátora kérte fel Brezsnyánszky Lászlót és M. Nádasi Máriát, hogy társelnökként szervezzék és irányítsák a neveléstudományi mesterszak képesítési követelményeit kidolgozó munkacsoportot, amelybe hét felsőoktatási intézmény delegált képviselőket: Debreceni Egyetem, Eszterházy Károly Főiskola, Eötvös Loránd Tudományegyetem, Nyíregyházi Főiskola, Pannon Egyetem, Pécsi Tudományegyetem és Szegedi Tudományegyetem (Brezsnyánszky \& M. Nádasi, 2008).

A neveléstudományi mesterszak képzési programja az alapszakok szemszögéből szélesen befogadó volt már a kezdetekben is (teljes beszámítással: pedagógia BA, tanító, óvodapedagógus, konduktor, gyógypedagógus szakok, feltétellel: szociálpedagógia, viselkedéselemző, andragógia szakok), feltételezett közös alapismereteket, a mesterszak programjában az alapszak tanulmányi területeinek és kom- 
petenciáinak tovább építésére, mélyítésére törekedett, széles szakirány választékot kínált. Szakmai tudás és készségek terén pedig biztosította a megfelelő utánpótlást a neveléstudományi doktori képzés számára (Brezsnyánszky \& M. Nádasi, 2008).

A 2007 áprilisában akkreditált képzési program szerint a neveléstudományi mesterszak célja:

„Olyan szakemberek képzése, akik széles körü, mester szintű szaktudományos és alkalmazói tudással rendelkeznek a neveléstudomány művelés és alkalmazása területén. A képzés során kialakult kompetenciák alapján képesek a köz- és felsőoktatásban, illetve az oktatásügyben kutatói vagy alkalmazói feladatokat ellátni, részt vállalni a rendszerszintű múködtetés feladataiból, a kutatás és fejlesztés terén feladatokat végezni, hazai és nemzetközi szakmai fórumokon a nevelésügy hazai eredményeit kommunikálni. Megfelelő ismeretekkel rendelkeznek tanulmányaik doktori képzés keretében történő folytatásához." (15/2006 OM rendelet).

A Magyar Akkreditációs Bizottság 11 szakirány részletes bemutatásával együtt 2007. április 3-án fogadta el a neveléstudományi mesterszak programját. Az induláskor elfogadott szakirányok:

- Kora gyermekkor pedagógiája

- Családpedagógia

- Segítő-fejlesztő pedagógia

- Multikulturális nevelés

- Gyermek- és ifjúsági tanulmányok

- Felsőoktatás-pedagógia

- Intézményfejlesztés

- Nevelési és oktatási kutatások

- Mérés és értékelés

- Elméleti és történeti kutatások

- Tanterv- és programfejlesztés

Az országban elsőként 2007 szeptemberében indult az első évfolyam neveléstudományi mesterszakon az ELTE PPK-n, Kora gyermekkor pedagógiája szakirányon. Az indításkor az egyetem két kara között (PPK és TÓK) együttmüködési megállapodás jött létre, a TÓK vállalta a neveléstudományi mesterszakon belül a Kora gyermekkor pedagógiája szakirány gondozását, szakmai megvalósítását (Hunyadyné, 2019). 
A Kora gyermekkor pedagógiája szakirány programját egy tanító- és óvóképző intézmények szakembereiből álló team dolgozta ki pályázati keretben: Bábosik István, Hunyady Györgyné, Kurucz Rózsa, Lőrincz Ildikó PhD, Szabados Lajos, Varga Gyula (Hunyadyné, 2019).

Hasonló célú és tartalmú képzés korábban nem volt a hazai felsőoktatásban. A szakirány programját úgy kellett kialakítani, hogy az a mesterszak törzsanyagát kiegészítve egyszerre legyen a tanító, óvodapedagógus szakok mesterszintủ folytatása és bevezetés a korosztály iránt érdeklődő más alapszakosok számára egy nemzetközileg is egyre fontosabbá váló problémakörbe. A tanító és az óvodapedagógus szakos hallgatók erősen gyakorlati irányultságú pedagógiát tanulnak, felkészültségükből egyes elméleti tárgykörök s a pedagógiai kutatásokra vonatkozó mélyebb módszertani ismeretek hiányoznak, így többnyire integrált tantárgyak kerültek kidolgozásra, amelyek szemléletmódjukban, korszerủségükben, konkrét tartalmukban meghaladták a tanító-, óvóképzés anyagát s eltértek a pedagógia BA tervezett tananyagától is (Hunyadyné, 2019).

A Kora gyermekkor pedagógiája szakirány célja, hogy a szakirányon szerzett kompetenciák birtokában a szakon végzettek:

- „képesek legyenek támogatni a kora gyermekkori intézményes nevelési folyamatokat,

- képesek legyenek szakértőként foglalkozni képzési programok tervezésével, fejlesztésével és értékelésével,

- felkészüljenek a kora gyermekkort érintő kutatások végzésére,

- bekapcsolódjanak oktatóként a felsőoktatásba, a pedagógusképzésbe (pl. tanító, óvodapedagógus, kisgyereknevelő szakon)” (Hunyadyné, 2019, p. 300).

A szakirány a továbbtanulni vágyó tanítóknak és óvodapedagógusoknak a kiteljesedés és elmélyülés lehetőségét is nyújtja, a 0-12 éves korosztály neveléséhez kapcsolódó kompetenciák gazdagodásával. Tudományos perspektívát is jelenthet a gyakorlatorientált tanítóknak, óvodapedagógusoknak és az utóbbi években már a kisgyereknevelőknek is. Nem utolsósorban maga a neveléstudomány is gazdagodik, fejlődik ennek az érzékeny életkori szakasznak a tanulmányozása, kutatása által (Hunyadyné, 2019).

Az ELTE-n a képzés első évtizedében a nappali és levelező tagozaton is hirdetett Kora gyermekkor pedagógiája szakirány volt a legnépszerủbb, a mesterszakosok 73\%-a -a választotta ezt a szakirányt (Hunyadyné, 2019). 
2013/2014-ben jelentősebb fejlesztést hajtottunk végre a szakirány képzési programján. Egyrészt a korai fejlesztés, a korai évek nevelésének fejlődéstámogató lehetőségeire irányuló fokozott figyelem, másrészt a csecsemő- és kisgyermeknevelő szak 2009-es akkreditálása tette szükségessé, hogy a szakirány a legkorábbi évekkel, a 0-3 éves korosztály nevelésével is foglalkozzon. A program struktúráját megőrizve a meglévő tantárgyak tartalma bővült a korai életkorok fejlődésének, nevelésének témakörével. 2013/2014-ben volt először lehetősége kisgyereknevelőknek jelentkezni a neveléstudományi mesterszakra (Hunyadyné, 2019).

2016-ban új képzési és kimeneti követelmények jelentek meg (18/2016. (VIII. 5.) EMMI rendelet), mely szükségessé tette a neveléstudomány mesterszak képzési programjának átdolgozását, szakmai gyakorlat is helyet kapott a képzésben.

Az elmúlt 12 évben mintegy 1800 fő nyert felvételt a neveléstudomány mesterszakra (1. ábra).

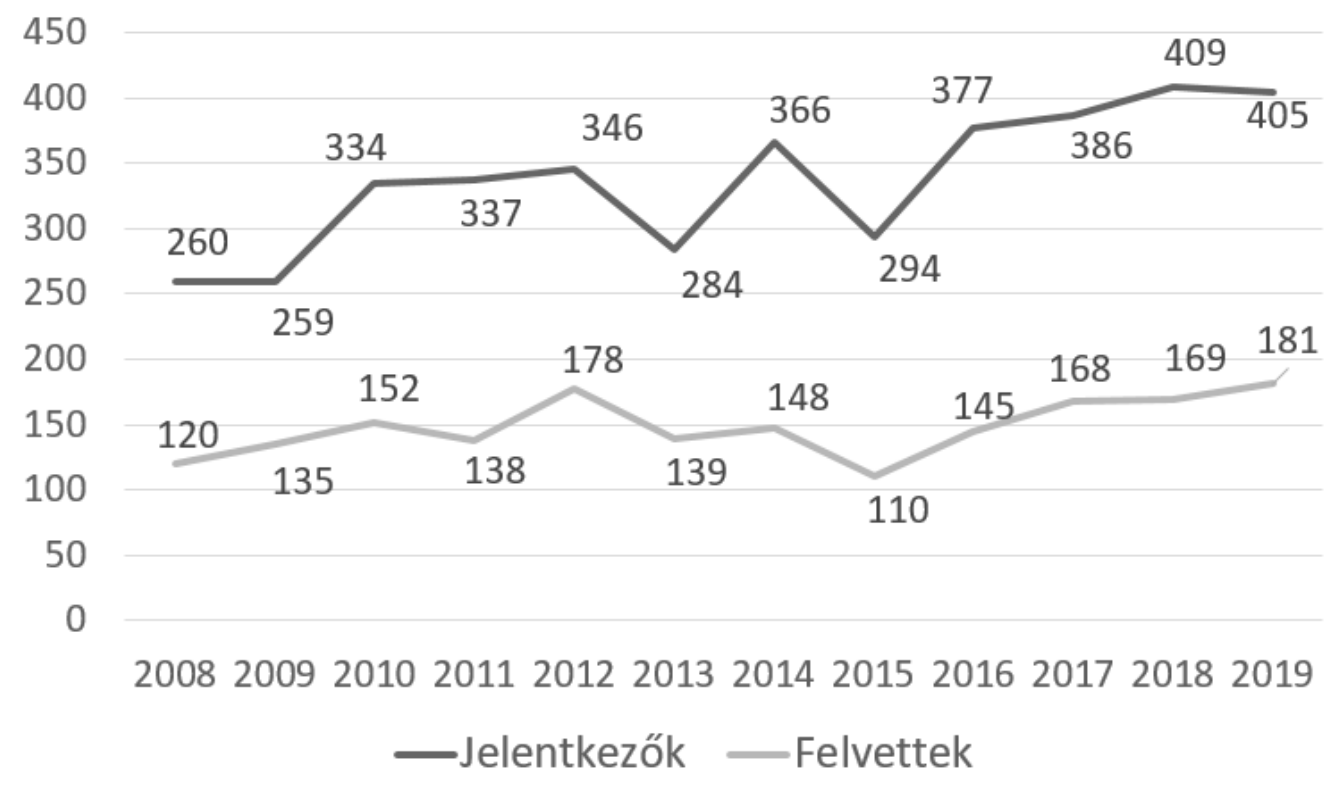

1. ábra A neveléstudomány(i) mesterszakra jelentkezők és felvettek száma (forrás: felvi.hu)

A felsőoktatás állandó változása a neveléstudományi mesterszakra is hatott. Bővült a specializációk köre. Az alapításhoz képest új specializációkat dolgoztak ki az intézmények:

- oktatásmenedzsment,

- tankönyv- és tananyagfejlesztés, 
- színházi nevelés és színház-pedagógia,

- kutató-elemző,

- fenntarthatóság és társadalom,

- kora gyermekkori intervenció.

Ma már kilenc felsőoktatási intézmény hirdet neveléstudomány mesterszakot változatos specializációkkal, melyekben tükröződnek az adott intézmény meghatározó neveléstudományi paradigmái, az észlelt igények, a képzők kompetenciái és szakmai elképzelései. Szinte minden helyen van részidős képzési forma is a nappali mellett. (1. táblázat) Az ELTE-n 2019-ben elindult az angol nyelvủ képzés is.

\begin{tabular}{|c|}
\hline $\begin{array}{l}\text { AVKF - Apor Vilmos Katolikus Főiskola (nappali - Vác, levelező - Budapest) } \\
\text { családpedagógia; segító-fejlesztó pedagógia specializáció }\end{array}$ \\
\hline $\begin{array}{l}\text { DE BTK - Debreceni Egyetem Bölcsészettudományi kar (nappali - Debrecen) } \\
\text { nevelési és oktatási kutatások; oktatásmenedzsment; segitó-fejlesztó pedagógia } \\
\text { specializáció }\end{array}$ \\
\hline $\begin{array}{l}\text { EKE PK - Eszterházy Károly Egyetem Pedagógiai Kar (nappali, levelező - Eger) } \\
\text { kora gyermekkor pedagógiája specializáció }\end{array}$ \\
\hline $\begin{array}{l}\text { ELTE PPK - Eötvös Loránd Tudományegyetem Pedagógiai- és Pszichológiai Kar } \\
\text { (nappali, esti - Budapest) } \\
\text { felsőoktatás-pedagógia; kora gyermekkor pedagógiája; színházi nevelés és színház- } \\
\text { pedagógia, intézményfejlesztés; kutató-elemzó specializáció }\end{array}$ \\
\hline $\begin{array}{l}\text { KE PK - Kaposvári Egyetem Pedagógiai Kar (nappali, levelező) (2020. februárban } \\
\text { elöször) } \\
\text { kora gyermekkori intervenció specializáció }\end{array}$ \\
\hline $\begin{array}{l}\text { PE MFTK - Pannon Egyetem Modern Filológiai és Társadalomtudományi Kar (nappali, } \\
\text { levelező - Veszprém) } \\
\text { felsőoktatás-pedagógia; kora gyermekkor pedagógiája specializáció }\end{array}$ \\
\hline $\begin{array}{l}\text { PTE BTK - Pécsi Tudományegyetem Bölcsészettudományi Kar (nappali, levelező) } \\
\text { kora gyermekkor pedagógiája; tanterv- és programfejlesztés specializáció }\end{array}$ \\
\hline $\begin{array}{l}\text { SOE BPK - Soproni Egyetem Benedek Elek Pedagógiai Kar (nappali, levelező) } \\
\text { fenntarthatóság és társadalom; kora gyermekkor pedagógiája specializáció }\end{array}$ \\
\hline $\begin{array}{l}\text { SZTE BTK - Szegedi Tudományegyetem Bölcsészet- és Társadalomtudományi Kar } \\
\text { (nappali, levelező) } \\
\text { kora gyermekkor pedagógiája; mérés és értékelés; segítő-fejlesztő pedagógia specializáció }\end{array}$ \\
\hline
\end{tabular}

1. táblázat 2020-ban neveléstudomány mesterszakot hirdető intézmények (forrás: felvi.hu)

A képzés során és után gyüjtött hallgatói visszajelzésekből kirajzolódik, hogy mit is jelent a mesterszak a tanítók, óvodapedagógusok és más alapszakot végzettek számára. Az önképzés és az új ismeretek szerzésének igénye, a szakmaiszellemi fejlődés vágya hozza a mesterszakra a pedagógusokat. Szeretnék megismerni a legújabb pedagógiai paradigmákat, remélik, hogy ezáltal szakmai és álta- 
lános világszemléletük is formálódik. Az újabb szakképzettség megszerzésétől nagyobb munkahelyi megbecsülést, esetleg a munkahely módosítás lehetőségét remélik. Ez azonban a mesterszak egyik legnagyobb megoldatlan problémája, hogy a munkaerőpiacon, a pedagógus pályán a mesterszakot végzettek anyagi megbecsülése továbbra is csak lehetőség, nem automatikusan ismerik el a magasabb végzettséget (Serfőző, 2020).

A mesterszakon hangsúlyos a hallgatók önálló és kritikai gondolkodásának fejlesztése, a horizontális tanulás lehetőségének előtérbe helyezése. Ez sok, együttműködésre építő munkamódszerben jelent meg: szakmai viták, gyakorlati tapasztalatok elemzése, mindennapi szituációk feldolgozása, mely révén a hallgatók eljuthattak az általánosabb pedagógiai-pszichológiai-szociológiai elvek megértéséig. Önálló feladatok és hosszabb kifutású, csoportos munkák révén zajlik a tanítástanulás. Ilyen projektorientált szervezésű feladat például a kutatási műhelymunka, melynek koncepcióját az ELTE-n Hunyady Györgyné és M. Nádasi Mária (2011) dolgozta ki. Gondolkodásuk alaptétele volt, hogy bár a mesterszaknak nem kutatók képzése a célja, az egyetemi végzettséget szerzett bölcsészektől elvárhatók kutatásmódszertani kompetenciák: például, hogy értően tudják olvasni és felhasználni az új tudományos eredményeket, képesek legyenek szakszerúen vizsgálni pedagógiai tevékenységük sajátosságait és eredményeit. A Kora gyermekkor pedagógiája szakirányon szemléletformálás szempontjából is hiánypótló az „alkalmazott kutatásmetodika” tanulása, mely a kora gyermekkori neveléssel és intézményi múködéssel kapcsolatos kutatások specifikus kérdéseit tárgyalja. A mühelymunka projekt révén a hallgatók érzékenyebbé válnak a kutatásmetodikai kérdések iránt, felismerik az életkor és a kutatási stratégia összefüggéseit, megér tik a gyerekek életkorából, helyzetéből, a velük foglalkozó intézmény jellemzőiből adódó módszertani sajátosságokat és nem utolsó sorban megtapasztalják az együttműködésben végzett kutatás előnyeit és kihívásait (Hunyadyné \& M. Nádasi, 2011).

A mesterképzés értéke a hallgatók sokszínű előképzettsége, szakmai tapasztalatainak heterogenitása. Az aktív bevonásra építő, horizontális tanulást előtérbe helyező módszerek alkalmasak az ebben rejlő lehetőségek kiaknázására is, melynek előnyeit az oktatók és a hallgatók is egyaránt elismerik és élvezik (Serfőző, 2020).

A képzés végén közvetlenül és pár év elteltével adott visszaemlékezések is azt tükrözik, hogy a hallgatók szakkal, szakiránnyal kapcsolatos várakozásai nagy- 
részt teljesülnek. Változatos, sokrétü, munkájukat és általában az életüket is segítő képzést kapnak. Tudatosabb, felkészültebb szakemberekké válnak, rálátást szereznek korábbi ismereteikre, nyitottabb, problémaorientáltabb lesz szemléletük. A makroszintű folyamatok értelmezésében is tájékozottabbak, jobban érvelnek, magabiztosabban használják a szaknyelvet (Serfőző, 2020).

Visszatekintve, a kezdeti célok megvalósultak. A neveléstudományi mesterszak kidolgozása szakmai előrelépés a tanító- és óvóképzés fejlődésében. Lehetőséget ad arra, hogy egy tanító, óvodapedagógus, kisgyereknevelő, konduktor, gyógypedagógus stb. elméleti ismereteit bővítve bekapcsolódjon valamilyen fejlesztői, szakértői munkába, részt vegyen a pedagógusképzésben oktatóként vagy éppen a gyakorlati képzés mentoraként, alakítójaként. Sokak számára ez egyfajta szakmai továbbfejlődés, kitekintés, amely révén az alapszaknak megfelelő státuszban dolgoznak tovább, de kidolgozottabb, megalapozottabb szakmai műveltséggel. Többen tovább léptek a doktori képzés irányába is.

Miként az induláskor, most is vannak alternatív elképzelések és utak. Kidolgozásra került, elfogadásra vár a gyermekkultúra mesterszak. A tanítók a mủveltségi területről tovább léphetnek a tanárképzésbe rövid ciklusú képzésben. Nemzetközi együttmúködések is épülnek közös képzések formájában. Ezek valódi hasznosulásáról és arról, hogy a hallgatók a mesterszak után a pályán maradnak-e, a koragyermekkori nevelés területén dolgoznak-e tovább, még nincs, nem lehet elegendő információnk. Lehetőség van más mesterszakokra is jelentkezni (például emberi erőforrás tanácsadó), amelyek azonban egyértelmủen pályamódosítást jelentenek, így már nem értelmezhetők a kiinduló, szakmai előrelépést biztosításáról gondolkodó keretben.

Bár az írásmủ alapjául szolgáló előadást még személyesen hallgatta Hunyady Györgyné, mára már nincs közöttünk. A neveléstudományi mesterszak történetének, benne a Kora gyermekkor pedagógiája szakirány koncepciójának végig gondolása tükrözi Hunyady Zsuzsa világos koncepcióját arról, hogy a szak és annak Kora gyermekkor pedagógiája szakiránya mivel járulhat hozzá a hallgatók, a koragyermekkori nevelésben szerepet vállaló pedagógusok és egyáltalán a szakterület fejlődéséhez. Szakirányfelelősi munkája, elképzeléseinek következetes megvalósítása által ez a nem diszciplináris, hanem életkori pedagógiai feladatok alapján szerveződő szakirány sajátos profilú, koherens tartalmú képzéssé vált. 


\section{Irodalom}

15/2006. (IV. 3.) OM rendelet az alap- és mesterképzési szakok képzési és kimeneti követelményeiről

18/2016.(VIII. 5.) EMMI rendelet A felsőoktatási szakképzések, az alap- és mesterképzések képzési és kimeneti követelményeiről... Magyar Közlöny 116. sz 2016. aug. 5. 10 408-11971.

252/2004. (VIII. 30.) Kormányrendelet A többciklusú, lineáris felsőoktatási képzési szerkezet bevezetésének egyes szabályairól és az első képzési ciklus indításának feltételeiről

Bollókné Panyik, I. \& Hunyady Györgyné (2003). A tanítóképzés az integrált felsőoktatásban. Új Pedagógiai Szemle, 53(7-8), 7-14.

Brezsnyánszky, L. \& M. Nádasi, M. (2008). A neveléstudományi mesterprogramok helyzete és problémái. Áttekintés az MTA Pedagógiai Bizottsága számára. Pedagógusképzés, 6(4), 53-69.

Hunyady Györgyné (2019). Együttműködés a neveléstudományi mesterszak gazdagításáért. In Baska, G., Hegedűs, J. \& Szabó, Z. A. (Eds.). Visszhangzó századok - tanulmányok, ünnepi írások Szabolcs Éva tiszteletére (pp. 300-311), ELTE PPK - L'Harmattan Kiadó.

Hunyady Györgyné \& M. Nádasi, M. (2011). A műhelymunka egy lehetséges módszertani megoldása. Pedagógusképzés, 9(1-2), 117-129.

Serfozzö, M. (2020). A „zsákutca” megnyitása - Mesterképzés a koragyermekkor pedagógusainak. Konferencia Dr. Hunyady Zsuzsa emlékére. Takács Etel Pedagógiai Alapítvány, ELTE, 2020. 02. 01.

https://www.felvi.hu/felveteli/ponthatarok_statisztikak/elmult_evek/!

ElmultEvek/index.php/elmult_evek_statisztikai/tobbciklus-mester-szakok (2020. 03. 08.)

https:/www.felvi.hu/felveteli/szakok_kepzesek/szakkereso/!Szakkereso/ index.php/szakkereso/index (2020. 03. 08.) 


\section{Education at Master Level for Primary School Teachers}

2006 was a milestone in primary school teacher training since Government Decree 252/2004. (VIII. 30.) was introduced. The "multiple cycle, linear structure of higher education" provided learning opportunities for graduated primary school teachers contrary to the previous situation. The foundation of Educational Science MA supported this process. Teachers of early childhood education and primary school level could continue their education without the need of changing their carrier or professional interests. After graduating from MA the opportunity of continuing studies on doctoral level was also provided for them.

This paper introduces the short history and characteristics of Educational Science MA and the concept of Childhood Studies Specialization is details. It also reflects on the principles and aspects that characterized the thinking of Hunyady Györgyné about role played by master level education in professional development of students and in-service early childhood education- and primary school teachers.

Key words: elementary school teacher education, educational science MA, early childhood education 